\title{
Effect of small variations in salinity on the rates of photosynthesis and respiration of the zooxanthellate coral Stylophora pistillata
}

\author{
C. Ferrier-Pagès ${ }^{1, *}$, J.-P. Gattuso ${ }^{2}{ }^{\text {, J. Jaubert }}{ }^{1}$ \\ 'Observatoire Océanologique Européen, Centre Scientifique de Monaco, Av. Saint-Martin, MC-98000, Monaco \\ ${ }^{2}$ Observatoire Océanologique, LOBEPM, UPRESA 7076, CNRS, BP 28, F-06234 Villefranche-sur-Mer cedex, France
}

\begin{abstract}
This paper deals with the effect of a long term ( $3 \mathrm{wk}$ ) change in salinity (increase or decrease of 2 to $4 \mathrm{psu}$ ) on the rates of photosynthesis and respiration of the zooxanthellate coral Stylophora pistillata. Colonies were exposed to 4 levels of salinity $(34,36,38$ and $40 \mathrm{psu}$, with $38 \mathrm{psu}$ as the control salinity) and results were compared using 1 -factor ANOVAs. Salinity had a significant effect on the protein concentration. It was $30 \%$ higher at 38 psu than at the other salinities. It had also a significant effect on the rates of photosynthesis, respiration and on the $P_{\mathrm{g}}: R$ ratio. Gross maximal photosynthetic rates were $50 \%$ lower at 34,36 and 40 psu than at $38 \mathrm{psu}$. The $P_{\mathrm{g}}: R$ ratio was always higher at the control salinity. Most of the colonies maintained at 40 psu died and this was explained by a very low $P_{\mathrm{g}}: R$ ratio $(<1)$. S. pistillata is therefore especially sensitive to small changes in salinity and seems to acclimate more easily to hypo- rather than to hypersaline conditions.
\end{abstract}

KEY WORDS: Scleractinian - Coral - Photosynthesis - Respiration. Salinity

Coral reefs are frequently subject to variations in seawater salinity, due to precipitation, storms, freshwater runoff, periods of prolonged drought or desalination processes (Coles \& Jokiel 1992, Leichter et al. 1996). Corals have no mechanisms of osmoregulation (Muthiga \& Szmant 1987); therefore, a change in salinity may affect their metabolism and survival capacities, even if they have been shown to exhibit some ability for acclimation to physical stresses (Muthiga \& Szmant 1987, Coles 1992, Brown 1997). The effects of salinity on reef corals have not been thoroughly studied, maybe because it has been considered that most coral reefs occur in waters with a relatively stable salinity. However, it has been demonstrated that the salinity of tropical waters may have shown large fluctuations in the past (Correge \& De-Decker 1997).

·E-mail: ferrier@naxos.unice.fr
In a recent paper, Moberg et al. (1997) provided evidence that most of the literature on the subject is over 50 yr old. It mainly deals with field observations which suggest that a large variation in salinity (>10 psu) has a lethal effect on most species (see Coles \& Jokiel 1992 for a review). More recent in situ studies have also observed that a rapid and important change in salinity may induce death (Sakai et al. 1989, Coles \& Jokiel 1992, Jokiel et al. 1993), bleaching (Glynn 1993), and histopathological changes (Van Woesik et al. 1995). To our knowledge, few studies have experimentally assessed the effect of sublethal salinity changes on corals (Muthiga \& Szmant 1987, Coles 1992, Moberg et al. 1997. Nakano et al. 1997). Muthiga \& Szmant (1987) and Moberg et al. (1997) studied the effect of a 10 to 20 psu rapid change in salinity on the rates of respiration and photosynthesis of the hermatypic corals Siderastrea siderea, Porites lutea and Pocillopora damicornis. Coles (1992) raised or lowered normal salinities by $10 \mathrm{psu}$ and assessed the tolerance of some corals according to their salinity history. The above studies have mainly dealt with large variations in salinity over a short incubation time. Only 1 experiment (HoeghGuldberg \& Smith 1989) studied the export of zooxanthellae under a low change in salinity (5 psu) during a long term incubation (20 d).

The objectives of this experiment were to complement the previous studies and to determine the long term effect ( $3 \mathrm{wk}$ ) of small variations in salinity (increase or decrease of 2 to 4 psu) on the physiological responses of the Red Sea coral Stylophora pistillata. Small decreases in salinity over a long time scale often occur near sewage discharge, rivers or during long rainy seasons and major storms (see Coles \& Jokiel 1992 for a review). Several hurricanes, for instance, occurring in the Caribbean in the 1980s, have significantly lowered the seawater salinity in some places for several days (Brown 1997). In 1965, 2 high rainfall 
events in Kaneohe Bay, Oahu, Hawaii, lowered salinity for more than $3 \mathrm{wk}$ and resulted in the death of corals and other benthic organisms (Coles \& Jokiel 1992). Increases in salinity can be observed in shallow reef waters and are now occurring in several tropical regions where desalination techniques are used to supply freshwater for human use. Yet, the physiological responses of corals are not well known. Moreover, although coral reefs are usually considered to have limited salinity tolerances, they also occur, under natural conditions, at salinities ranging from 25 to 42 psu (Coles 1992, Coles \& Jokiel 1992); this suggests that there should be some adaptations to extreme environments. S. pistillata was chosen because it has a wide geographic distribution throughout the Indo-Pacific and is common in most shallow water reefal areas as well as in deep water and lagoons. It has moreover been used in numerous biological and physiological studies (Crossland 1987, Hoegh-Guldberg \& Smith 1989, Rahav et al. 1989).

Material and methods. Experimental design: Experiments were performed in the laboratory, under controlled conditions, with colonies of Stylophora pistillata originating from the Gulf of Aqaba (Red Sea, 29 $30^{\prime} \mathrm{N}$, $34^{\circ} 58^{\prime} \mathrm{E}$ ) but maintained for several years in aquaria supplied with Mediterranean seawater (salinity $=38 \pm$ $0.4 \mathrm{psu}$ ). Thirty-two nubbins were prepared from 4 parent colonies ( 8 nubbins colony ${ }^{-1}$, as described by Al-Moghrabi et al. (1993). Terminal portions of branches were cut with pliers from parent colonies, attached to a nylon wire and suspended in a culture aquarium. Light was provided by metal halide lamps (Philips, HPIT $400 \mathrm{~W}$ ); irradiance was $250 \mu \mathrm{mol}$ photons $\mathrm{m}^{-2} \mathrm{~s}^{-1}$ (photo-period 12:12 h). The aquarium was supplied with Mediterranean seawater (pumped at $50 \mathrm{~m}$ depth and heated to $25 \pm 0.5^{\circ} \mathrm{C}$ ). This water was not filtered, had low nutrient concentrations $(<0.4 \mu \mathrm{M}$ ammonium, $<1 \mu \mathrm{M}$ nitrate, $<0.2 \mu \mathrm{M}$ phosphorus), low chlorophyll a (chl a) concentrations (0.2 to $0.3 \mu \mathrm{g} \mathrm{l}^{-1}$ ) and an aragonite saturation state ranging between 3.1 and 3.7 (NBS pH and dissolved inorganic carbon ranged, respectively, from 8.1 to 8.2 and from 2.3 to $2.4 \mathrm{mmol} \mathrm{kg}^{-1}$ ). After approximately $1 \mathrm{mo}$, tissue had grown over the exposed skeleton and coral fragments were entirely covered with new tissue.

Two nubbins from each parent colony were transferred into 4 tanks (15 l) containing seawater at 4 different salinities $(34,36,38,40 \mathrm{psu})$. The 38 psu salinity tank served as a control. All tanks were aerated and maintained under similar temperature $\left(25^{\circ} \mathrm{C}\right)$ and light (250 $\mu \mathrm{mol}$ photons $\mathrm{m}^{-2} \mathrm{~s}^{-1} ; 12: 12 \mathrm{~h}$ photo-period) conditions. They were continuously supplied with Mediterranean seawater, either diluted with freshwater to a salinity of 34 and 36 psu or enriched with high salinity (50 psu) artificial seawater (Instant Ocean) to a salinity of 40 psu. Salinity levels were maintained constant using a peristaltic pump and were measured with a portable induction salinometer (Conductivity meter LF 196) calibrated with standard seawater (IAPSO, Ocean Scientific International). Nubbins were incubated for $3 \mathrm{wk}$ and rates of photosynthesis and respiration were measured at the end of the incubation.

Physiological measurements: Photosynthesis and respiration were measured on 5 nubbins taken randomly from each tank after 3 wk incubation at the different salinities. Nubbins were incubated in a perspex chamber containing a polarographic oxygen sensor (Ponselle) and immersed in a thermostated water bath $\left(25^{\circ} \mathrm{C}\right)$. The chamber was filled with Millipore $(0.45 \mu \mathrm{m})$ filtered seawater at the different salinity levels. The incubation medium was continuously stirred with a magnetically coupled stirring bar and changed every $15 \mathrm{~min}$. Changes in dissolved oxygen levels were measured under different irradiances $(0,40,80$, $120,170,200,300$ and $400 \mu \mathrm{mol}$ photons $\mathrm{m}^{-2} \mathrm{~s}^{-1}$ ). Light was provided by a $400 \mathrm{~W}$ metal halide lamp (Philips, HPIT), attenuated to the desired intensity with neutral screens. The oxygen sensor was calibrated before each experiment against air-saturated seawater and a saturated solution of sodium dithionite (zero oxygen). Oxygen was recorded every minute on a LI-COR LI-1000 datalogger. Rates of photosynthesis and respiration were estimated by regressing oxygen data against time. Data were normalized either by protein or by chl a content of the colony. Net photosynthetic rates were calculated according to the following equation

$$
P_{\text {net }}=(V \times \text { slope }) / \mathrm{chl} \mathrm{a}
$$

where $P_{\text {net }}=$ rate of net photosynthesis $\left(\mu \mathrm{mol} \mathrm{O}_{2} \mathrm{~g}^{-1} \mathrm{chl}\right.$ $\left.\min ^{-1}\right)_{i} V=$ chamber volume $(1)$; slope = dissolved oxygen variation ( $\mu \mathrm{mol} \mathrm{O}_{2} \mathrm{l}^{-1} \mathrm{~min}^{-1}$ ); and chl a = chlorophyll a content of the colony (mg). An exponential function was fitted to the photosynthesis-irradiance (PI) data using MacCurveFit:

$$
P_{\text {net }}=P_{\mathrm{g} \max }\left[1-\exp \left(-I / I_{k}\right)\right]+r
$$

where $P_{g \max }=$ gross maximum photosynthetic rate

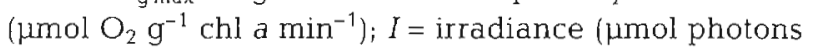
$\left.\mathrm{m}^{-2} \mathrm{~s}^{-1}\right)_{i} I_{k}=$ Talling parameter ( $\mu \mathrm{mol}$ photons $\mathrm{m}^{-2} \mathrm{~s}^{-1}$ ); and $r=$ respiration rate in the dark $\left(\mu \mathrm{mol} \mathrm{O} \mathrm{O}_{2} \mathrm{~g}^{-1} \mathrm{chl} a\right.$ $\min ^{-1}$ ).

The daily $P_{\mathrm{g}}: R$ ratios were estimated using the following equation:

$$
P_{g}: R=\left(P_{\mathrm{g}} \times 12\right) /(I \times 24)
$$

where $P_{\mathrm{g}}=$ hourly rate of gross photosynthesis at 300 $\mu \mathrm{mol}$ photons $\mathrm{m}^{-1} \mathrm{~s}^{-1}$ and $r=$ hourly respiration rate.

At the end of the experiments, colonies were frozen pending determination of protein and chlorophylls. $\mathrm{Chl} a$ and chl $c_{2}$ contents were extracted twice in $100 \%$ 
acetone $\left(24 \mathrm{~h}\right.$ at $\left.4^{\circ} \mathrm{C}\right)$. The extracts were centrifuged at $11000 \mathrm{rpm}(11035 \times \mathrm{g})$ for $10 \mathrm{~min}$ and the absorbances were measured at 630,663 and $750 \mathrm{~nm}$. Chlorophyll concentrations were computed according to the spectrophotometric equations of Jeffrey \& Humphrey (1975). Tissues were then solubilized in $1 \mathrm{~N} \mathrm{NaOH}$ at $90^{\circ} \mathrm{C}$ for $30 \mathrm{~min}$ and the protein content was measured, as described by Lowry et al. (1951), on 5 replicates $(1 \mathrm{ml})$ of the extract. The standard curve was established with bovine serum albumin standard and absorbance was measured at $750 \mathrm{~nm}$ using an Alliance autoanalyser. The contents of protein and chlorophyll were normalized by the skeletal weight (DW) of the nubbins.

The effect of salinity was assessed using 1-factor ANOVAs. When a significant effect was found, the means were compared with a Bonferroni/Dunn posthoc test. Statistical analysis was performed using StatView 4.01 for Macintosh computers. Data are reported as mean \pm standard error of the mean.

Results. Salinity had a significant effect on the protein concentration $\left(0.55\right.$ to $0.80 \mathrm{mg}\left[\mathrm{mg} \mathrm{DW}^{-1}\right.$; ANOVA, $p=0.02$; Fig. 1 ). It was 25 to $30 \%$ higher at 38 than at 34 and 40 psu. Many $(70 \%)$ of the nubbins maintained for more than 3 wk at 40 psu died. The chl a concentration was not significantly different between 34,36 and $38 \mathrm{psu}$ ( 6 to $7 \mathrm{mg}\left[\mathrm{mg} \mathrm{DW}^{-1}\right.$ ) but was significantly higher at $40 \mathrm{psu}\left(12 \mathrm{mg}[\mathrm{mg} \mathrm{DW}]^{-1}\right.$. ANOVA, $p=0.003$.

PI curves obtained after 3 wk incubation at the 4 salinities are shown in Fig. 2. The net maximal photosynthetic rates varied between 150 and $220 \mu \mathrm{mol} \mathrm{O}_{2}$ $\mathrm{mg}^{-1} \mathrm{chl} a \mathrm{~h}^{-1}$ at 34,36 and 40 psu and was equal to 410 to $430 \mu \mathrm{mol} \mathrm{O} \mathrm{O}_{2} \mathrm{mg}^{-1} \mathrm{chl} \mathrm{a} \mathrm{h}{ }^{-1}$ at the control salinity (38 psu). The PI curve parameters are shown in Table 1. There was a statistically significant effect of salinity on $P_{\mathrm{g}}$ and $r$ (ANOVA, $\mathrm{p}<0.001$ ). The gross maximal photosynthetic rate, $P_{\mathrm{g} \text { max }}$, either expressed

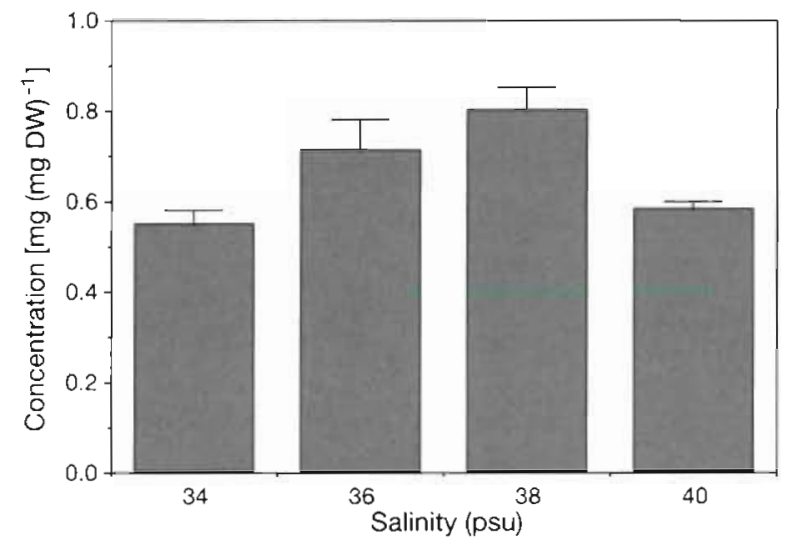

Fig. 1. Stylophora pistillata. Protein concentration as a function of salinity. Mean \pm standard error $(N=5)$. DW: skeletal weight

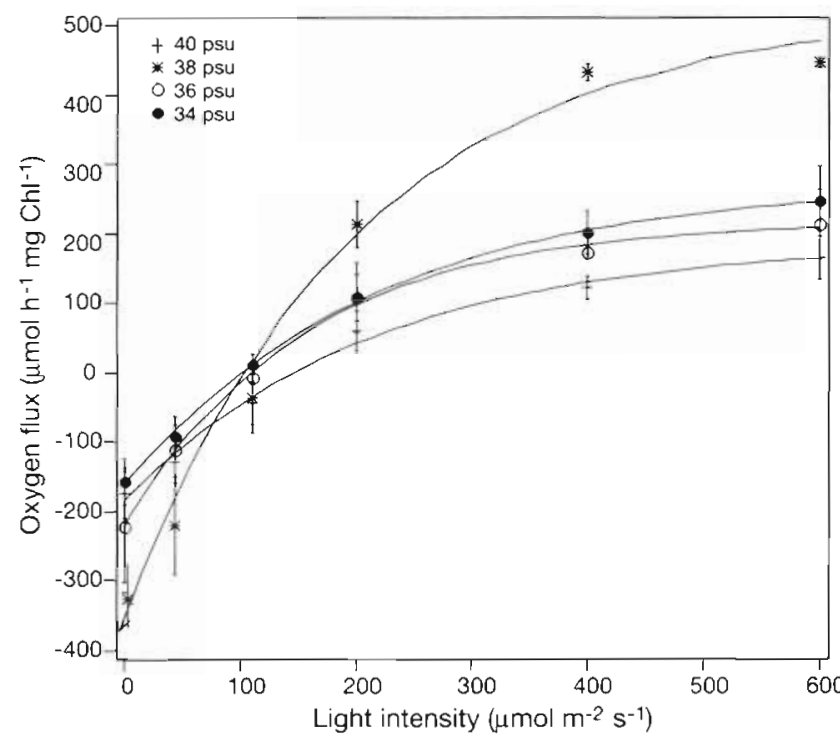

Fig. 2. Stylophora pistillata. Mean photosynthesis-irradiance curves measured for corals incubated at different salinities.

Data are mean and standard deviations of 5 replicates

Table 1. Data from the physiological measurements of Stylophora pistillata maintained for 3 wk under 4 different salinities. Data are mean and standard error of the mean. $P_{\mathrm{gmax}}$ : gross maximum photosynthetic rate; $r$ : respiration rate. The effect of salinity was assessed using 1 -factor ANOVAs. When a significant effect was found, the means were compared with a Bonferroni/Dunn post hoc test. $\mathrm{p}<0.05$ : significant

\begin{tabular}{|c|c|c|c|c|c|c|}
\hline \multirow{2}{*}{ Physiological parameter } & \multicolumn{4}{|c|}{ Salinity (psu) } & \multirow{2}{*}{$\begin{array}{l}\text { ANOVA } \\
\text { p }\end{array}$} & \multirow{2}{*}{$\begin{array}{l}\text { Post hoc test } \\
\text { significant results }\end{array}$} \\
\hline & 34 & 36 & 38 & 40 & & \\
\hline$P_{\mathrm{g} \max }\left(\mu \mathrm{mol} \mathrm{O} \mathrm{Ogg}^{-1} \mathrm{chl} \mathrm{h}^{-1}\right)$ & $496 \pm 19$ & $665 \pm 42$ & $1103 \pm 62$ & $318 \pm 06$ & $<0.0001$ & $\begin{array}{l}38 \text { psu higher than } 34,36,40 \\
36 \text { psu higher than } 34,40\end{array}$ \\
\hline$P_{g \max }\left(\mu \mathrm{mol} \mathrm{O}_{2} \mathrm{mg}^{-1}\right.$ protein $\left.\mathrm{h}^{-1}\right)$ & $5.5 \pm 0.8$ & $5.2 \pm 0.3$ & $8.5 \pm 0.1$ & $6.3 \pm 0.3$ & 0.003 & 38 psu higher than $34,36,40$ \\
\hline$r\left(\mu \mathrm{mol} \mathrm{O} \mathrm{mg}^{-1} \mathrm{chl} \mathrm{h}^{-1}\right)$ & $171 \pm 16$ & $269 \pm 12$ & $363 \pm 28$ & $184 \pm 20$ & 0.0005 & 38 psu higher than $34,36,40$ \\
\hline$r\left(\mu \mathrm{mol} \mathrm{O}_{2} \mathrm{mg}^{-1}\right.$ protein $\left.\mathrm{h}^{-1}\right)$ & $1.9 \pm 0.1$ & $1.6 \pm 0.2$ & $2.8 \pm 0.2$ & $3.9 \pm 0.3$ & 0.0003 & $\begin{array}{l}38 \text { psu higher than } 34,36 \\
40 \text { psu higher than } 34,36,40\end{array}$ \\
\hline$P_{\mathrm{g}}: R$ & $1.3 \pm 0.1$ & $1.2 \pm 0.1$ & $1.5 \pm 0.1$ & $0.9 \pm 0.1$ & 0.009 & 38 psu higher than 40 \\
\hline
\end{tabular}


in terms of chl a or protein, was always higher (30 to $50 \%$ ) at the control salinity, 38 psu (Bonferroni/Dunn, $\mathrm{p}<0.05$ ). $r$ was significantly higher (Bonferroni/Dunn, $p<0.05$ ) at 38 psu when expressed in terms of chl a and 40 psu when expressed in terms of protein. The $P_{\mathrm{g}}: R$ ratio also varied as a function of salinity (ANOVA, $\mathrm{p}=0.02$ ) and was higher at $38 \mathrm{psu}$. The $P_{\mathrm{g}}: R$ ratio at 40 psu $(0.9)$ was significantly lower than at 38 psu (Bonferroni/Dunn, $\mathrm{p}<0.05$ ).

Discussion. The $P_{\mathrm{g}}: R$ ratios obtained for colonies cultivated at 38 psu were close to those measured in shallow-water colonies of Stylophora pistillata $\left(P_{\mathrm{g}}: R=1.5\right.$; Falkowski \& Dubinsky 1981, McCloskey \& Muscatine 1984. Gattuso 1987). Small changes in salinity of 2 to 4 psu over 3 wk resulted in a significant decrease in the $P_{\mathrm{g}}: R$ ratio, which became lower than 1 at $40 \mathrm{psu}$, indicating that the primary production could not supply the carbon respiratory requirements any longer. This stress response is likely to explain the high mortality observed at $40 \mathrm{psu}$. The carbon imbalance results from changes in the rates of photosynthesis and respiration. These rates were slightly different depending on whether they were expressed in terms of chlorophyll or protein, since the protein content varied according to the treatment. We therefore choose to discuss the rates of photosynthesis in terms of chl a and the rates of respiration in terms of protein, a unit that is more closely related to metabolic expenditure.

The rates of maximum gross photosynthesis were reduced by $50 \%$ following a change in salinity. Contrary to our results, changes in salinity of less than 10 psu had no significant effect on the photosynthesis of Siderastrea siderea (Muthiga \& Szmant 1987), but colonies were maintained for only 2 to $4 \mathrm{~d}$ at low salinities. Moreover, this species has been reported to be abundant in shallow reef-flat of Caribbean coral reefs, which are likely to experience large salinity fluctuations. The largest decrease in $P_{\text {gmax }}$ of Stylophora pistillata occurred with a salinity increase from 38 to 40 psu. Colonies were originally collected in the Red Sea (Gulf of Aqaba), where salinity is closer to 40 than to 38 psu (Reiss \& Hottinger 1984), and Stylophora species are known to occur in the Indo-Pacific region, where salinities are well above average ocean values (Coles \& McCain 1990). They are also able to live in 45 to 48 psu salinity in other regions of the Red Sea and of the Arab Gulf (Kinsman 1964, Sheppard 1988). We therefore assumed that $S$. pistillata could afford an increase in salinity, but this was not the case in the present study since most of the colonies maintained for more than 3 wk at 40 psu died. This observation is in agreement with a previous study of Kinsman (1964), who showed that corals have generally less tolerance for hyperthan for hyposalinity. Marcus \& Thorhaug (1981) also reported for Porites sp. a range of upper and lower tol- erance in salinity variation equal to a 24 psu decrease and only a 12 psu increase relative to the normal seawater salinity. Sublethal symptoms were observed at $40 \mathrm{psu}$, the same as for $S$. pistillata in this study. As far as respiration is concerned, a significant decrease was observed following the reduction in salinity. This is in agreement with some previous observations (Muthiga \& Szmant 1987, Moberg et al. 1997). However, the response is different for an increase in salinity and depends on the species considered as well as on the exposure time. The rate of respiration increased in $S$. pistillata exposed for $3 \mathrm{wk}$ (this study) and decreased in S. siderea exposed for $2 \mathrm{~d}$ (Muthiga \& Szmant 1987). However, the combined response of photosynthesis and respiration resulted in significant changes in the carbon balance of both species. The $P_{\mathrm{g}}: R$ ratio was highest at the control salinity for both species and decreases at low and high salinities.

Most corals are symbiotic with zooxanthellae, a dinoflagellate which translocates a large fraction of its photosynthetic products to the coral for its metabolism (Muscatine 1967). Corals are often subject to bleaching (loss in zooxanthellae or in photosynthetic pigments per algal cell) following a sudden change in salinity (Goreau 1964, Egana \& DiSalvo 1982). Bleaching is generally followed by a decrease in photosynthetic rate (Steen \& Muscatine 1987, Lesser \& Shick 1989. Muscatine et al. 1991). The decrease in photosynthesis measured in this study for salinities of 34,36 , and 40 psu did not seem to be due to bleaching, since concentrations in chlorophyll were not significantly lower than at 38 psu. Muthiga \& Szmant (1987) also found no difference in chlorophyll content for a salinity change of less than 5 psu. The decrease in photosynthesis might be due to a contraction of polyps, which reduces the exposure of zooxanthellae to light (Muthiga \& Szmant 1987). Such a mechanical response has already been described in other anthozoan species (Shumway 1978, Moberg et al. 1997), Moreover, since most coelenterates are not able to control their osmotic pressure (Ranklin \& Davenport 1981), a change in salinity may also induce tissue damage (Van Woesik et al. 1995), as well as temperature stress inducing a host cell detachment (Gates et al. 1992). A severe tissue necrosis, followed by the death of the colonies, was indeed observed for corals incubated for more than 3 wk at a salinity of 40 psu. This may explain the decrease in protein concentrations observed for the nubbins maintained at 34,36 and 40 psu salinities.

Studies on a short time scale (few days) have shown that large variations in salinity ( $>10$ psu) induced a decrease in the rates of photosynthesis and respiration (Muthiga \& Szmant 1987, Moberg et al. 1997) whereas small changes had no significant effects (Muthiga \& Szmant 1987. Hoegh-Guldberg \& Smith 1989). To our 
knowledge, long term studies have not yet been performed, but salinity may sometimes change over a period of several weeks. Jokiel et al. (1993) as well as Engebretson \& Martin (1994) reported that heavy rains decreased seawater salinity for many days and Goreau (1964) observed that floodwaters during Hurricane Flora lowered the salinity by between 5 and 8 psu for more than 5 wk. Robblee et al. (1989) also observed monthly mean salinity values as high as $52 \mathrm{psu}$ in Florida Bay. In this study, performed on a relatively long time scale, we showed that small changes in salinity can severely affect the physiology of Stylophora pistillata.

Considerable variation in environmental tolerances exists between species (Williams \& Bunkley-Williams 1990, Brown 1997). The response of corals to a change in salinity is related to the strength and duration of the hypo/hypersaline exposure as well as to the species considered. Stylophora pistillata seemed to be especially sensitive to small changes in salinity. Sakai et al. (1989) indeed observed a very high mortality rate of $S$. pistillata following an 8 psu decrease in seawater salinity due to heavy runoff. Coles (1992) also found that S. pistillata was less salinity tolerant than Porites compressa. According to our results, $S$. pistillata seems able to acclimate more easily to hypo- rather than to hypersaline conditions. This result provides a better understanding of the physiology and ecology of one of the dominant species of the Indo-Pacific region.

Acknowledgements. Thanks are due to N. Ounais and to the staff of the aquarium at the Oceanographic Museum for providing corals, as well as to D. Pisani for technical assistance.

\section{LITERATURE CITED}

Al-Moghrabi S, Allemand D, Jaubert J (1993) Valine uptake by the scleractinian coral Galaxea fascicularis: characterization and effect of light and nutritional status. J Comp Physiol B 163:355-362

Brown BE (1997) Adaptations of reef corals to environmental stress. Adv Mar Biol 31:221-299

Coles SL (1992) Experimental comparison of salinity tolerances of reef corals from the Arabian Gulf and Hawaii. Evidence for hypersaline adaptation. Proc 7 th Int Coral Reef Symp 1:227-234

Coles SL, Jokiel PL (1992) Effects of salinity on coral reefs. In: Connell DW, Hawker DW (eds) Pollution in tropical aquatic systems. CRC Press Inc, London, p 147-166

Coles SL, McCain JC (1990) Environmental factors affecting benthic infauna communities of the Western Arabian Gulf. Mar Environ Sci 29:289-215

Correge T, De-Decker P (1997) Faunal and geochemical evidence for changes in intermediate water temperature and salinity in the western Coral Sea (Northeast Australia) during the Late Quaternary. Paleogeogr Paleoclim Paleoecol 131:183-205

Crossland CJ (1987) In situ release of mucus and DOC-lipid from the corals Acropora variabilis and Stylophora pistillata in different light regimes. Coral Reefs $6: 35-42$

Egana AC, DiSalvo LH (1982) Mass expulsion of zooxanthellae by Easter Island corals. Pac Sci 36:61-63

Engebretson H, Martin KLM (1994) Effects of decreased salinity on expulsion of zooxanthellae in the symbiotic sea anemone Anthopleura elegantissima. Pac Sci 48:446-457

Falkowski PG, Dubinsky Z (1981) Light-shade adaptation of Stylophora pistillata, a hermatypic coral from the Gulf of Eilat. Nature 289:172-174

Gates RD, Baghdasarian G, Muscatine L (1992) Temperature stress causes host cell detachment in symbiotic cnidarias: implications for coral bleaching. Biol Bull 182:324-332

Gattuso JP (1987) Ecomorphologie, métabolisme, croissance et calcification du scléractiniaire a zooxanthelles Stylophora pistillata (Golfe d'Aqaba, Mer Rouge). Influence de l'éclairement. PhD thesis, Univ Aix-Marseille II

Glynn PW (1993) Coral reef bleaching: ecological perspectives. Coral Reefs $12: 1-17$

Goreau TF (1964) Mass expulsion of zooxanthellae from Jamaican reef communities after hurricane Flora. Science 145:383-386

Hoegh-Guldberg O, Smith GJ (1989) The effect of sudden changes in temperature, light and salinity on the population density and export of zooxanthellae from the reef corals Stylophora pistillata Esper and Seriatopora hystrix Dana. J Exp Mar Biol Ecol 129:279-303

Jeffrey SW, Humphrey JF (1975) New spectrophotometric equations for determining chlorophyll $a, b, c_{1}$ and $c_{2}$ in higher plants, algae and natural phytoplankton. Biochem Physiol Pflanzen 167:191-194

Jokiel PL, Hunter CL, Taguchi S, Watarai L (1993) Ecological impact of a fresh-water 'reef kill' in Kaneohe Bay, Oahu, Hawaii. Coral Reefs 12:177-184

Kinsman DJJ (1964) Reef coral tolerance of high temperatures and salinities. Nature 202:1280-1282

Leichter JJ, Wing SR, Miller SL, Denny MW (1996) Pulsed delivery of subthermocline water to Conch Reef (Florida Keys) by internal tidal bores. Limnol Oceanogr 41: $1490-1501$

Lesser MP, Shick JM (1989) Effects of irradiance and ultraviolet radiation on photoadaptation in the zooxanthellae of Aiptasia pallida primary production, photoinhibition and enzymic defenses against oxygen toxicity. Mar Biol 102 $243-255$

Lowry OH, Rosenbrough NJ, Farr AL, Randall RJ (1951) Protein measurement with the Folin phenol reagent. J Biol Chem 193:265-275

Marcus J, Thorhaug A (1981) Pacific versus Atlantic responses of the subtropical hermatypic coral Porites spp. to temperature and salinity effects. Proc 4 th Int Coral Reef Symp 2:15-20

McCloskey J, Muscatine L (1984) Production and respiration in the Red Sea coral Stylophora pistillata as a function of depth. Proc R Soc Lond 222:215-230

Moberg F, Nyström M, Kautsky N, Tedengren M, Jarayabhand $P$ (1997) Effects of reduced salinity on the rates of photosynthesis and respiration in the hermatypic corals Porites lutea and Pocillopora damicornis. Mar Ecol Prog Ser 157:53-59

Muscatine L (1967) Glycerol excretion by symbiotic algae from corals and Tridacna and its control by the host. Science 156:516-519

Muscatine L, Grossman D, Doino J (1991) Release of symbiotic algae by tropical sea anemones and corals after cold shock. Mar Ecol Prog Ser 77:233-243

Muthiga NA, Szmant AM (1987) The effects of salinity stress 
on the rates of aerobic respiration and photosynthesis in the hermatypic coral Siderastrea siderea. Biol Bull 173: $539-551$

Nakano Y, Yamazato K, Masuhara H, Iso S (1997) Responses of Okinawan reef-building corals to artificial high salinity. Galaxea 13:181-195

Rahav BO, Dubinsky Z, Achituv Y, Falkowski PG (1989) Ammonium metabolism in the zooxanthellate coral Stylophora pistillata. Proc R Soc Lond 236:325-337

Ranklin JC, Davenport J (1981) Animal osmoregulation. Halsted Press, New York

Reiss Z, Hottinger L (1984) The Gulf of Aqaba, ecological micropaleontology. In: Billings WD, Golley F, Lange OL, Olson JS, Remmert H (eds) Ecological studies, Vol 50. Springer Verlag, Berlin

Robblee MB, Tilman JT, Emerson J (1989) Quantitative observations on salinity. Bull Mar Sci 44:523

Sakai K, Snidvongs A, Nishihira M (1989) A mapping of a

Editorial responsibility: Otto Kinne (Editor),

Oldendorf/Luhe, Germany coral-based, non-reefal community at Khang Khao Island, inner part of the Gulf of Thailand: interspecific competition and community structure. Galaxea 8:185-216

Sheppard CRC (1988) Similar trends, different causes: responses of corals to stressed environments in Arabian Seas. Proc 6th Int Coral Reef Symp 3:297-302

Shumway SE (1978) Activity and respiration of the sea anemone Metridium senile (L.) exposed to fluctuating salinities. J Exp Mar Biol Ecol 33:85-92

Steen RG, Muscatine L (1987) Low temperature evokes rapid exocytosis of symbiotic algae by sea anemone. Biol Bull 172:246-263

Van Woesik R, De Vantier LM, Glazebrook JS (1995) Effects of Cyclone 'Joy' on nearshore coral communities of the Great Barrier Reef. Mar Ecol Prog Ser 128:261-270

Williams EH Jr, Bunkley-Williams L (1990) The world-wide coral reef bleaching cycle and related sources of coral mortality. Atoll Res Bull 335

Submitted: October 6, 1998; Accepted: February 10, 1999 Proofs received from author(s): April 28, 1999 